\title{
PERAN GAYA KEPEMIMPINAN, BUDAYA ORGANISASI DAN REWARD TERHADAP KOMITMEN KERJA KARYAWAN
}

\author{
Lilik Kustiani $^{1}$, Diah Widiawati ${ }^{2}$, Kurnia Isnuwardiati ${ }^{3}$ \\ ${ }^{123}$ Fakultas Ekonomi dan Bisnis, Universitas Merdeka Malang, Indonesia
}

\begin{tabular}{l}
\hline ARTICLE INFORMATION \\
\hline ISSN: $2579-7204$ (Online) \\
ISSN: 0216-4132 (Print) \\
DOI: $10.26487 /$ jbmi.v18i1.13180. \\
\hline SUBMISSION TRACK \\
\hline Received: $9^{\text {th }}$ March 2021 \\
Final Revision: $14^{\text {th }}$ June 2021 \\
Available Online: $21^{\text {st }}$ June 2021 \\
\hline KATA KUNCI \\
\hline Budaya Organisasi, Gaya \\
Kepemimpinan, Komitmen, Reward
\end{tabular}

\section{KEYWORD}

Organizational Culture; Leadership

Style; Commitment; Reward

\section{CORRESPONDENCE}

Phone: 081334794922

E-mail: lilikkustiani36@gmail.com

\begin{abstract}
ABSTRAK
Karyawan yang mempunyai komitmen kerja yang tinggi mempunyai keinginan untuk mempertahankan diri menjadi anggota organisasi. Oleh karena itu, untuk mengembangkan suatu organisasi maka harus diperhatikan berbagai aspek yang mampu menciptakan komitmen kerja. Penelitian ini bertujuan untuk mengkaji: pengaruh gaya kepemimpinan terhadap komitmen kerja, pengaruh budaya organisasi terhadap komitmen kerja dan pengaruh reward terhadap komitmen kerja. Penelitian ini merupakan penelitian deskriptif kuantitatif dengan menggunakan analisa regresi berganda. Sampel dalam penelitian ini adalah seluruh karyawan di KOPPAS "Citra Kartini”" Senggreng Sumberpucung Kabupaten Malang berjumlah 39 karyawan. Hasil analisis data dalam penelitian ini dapat disimpulkan: gaya kepemimpinan berpengaruh positif signifikan terhadap komitmen kerja karyawan, budaya organisasi berpengaruh positif signifikan terhadap komitmen kerja karyawan, reward berpengaruh positif signifikan terhadap komitmen kerja karyawan, dan reward merupakan variabel yang berpengaruh dominan terhadap komitmen kerja karyawan
\end{abstract}




\section{PENDAHULUAN}

Koperasi merupakan sekumpulan kegiatan usaha yang dikelola oleh anggota koperasi dalam rangka memenuhi kebutuhan dari semua anggota koperasi, utamanya di bidang ekonomi, bidang sosial dan sekaligus merambah di bidang budaya. Koperasi menjadi suatu gerakan ekonomi yang berkembang pesat di Indonesia, dengan adanya kemajuan di bidang teknologi, menjadikan koperasi harus bisa menyesuaikan diri untuk mengikuti dan merespon berbagai tren serta perkembangan baru di tengah masyarakat yang semakin maju dalam pola pikirnya.

Salah satu upaya merespon perkembangan di era perkembangan teknologi atau era digital seperti sekarang ini adalah dengan mengadopsi teknologi informasi, baik untuk menangani manajemen maupun pelayanan bagi seluruh anggota koperasi. Karena dengan memiliki kemampuan di bidang teknologi informasi, mampu mengembangkan peluang eksistensi menghadapi persaingan pasar koperasi dan keuangan dan kompetitif. Penggunaan teknologi informasi, membantu koperasi menyampaikan informasi terkait tagihan simpan pinjam, pendaftaran anggota dan lain-lain. Selain itu, dengan teknologi informasi dapat membantu anggota mengontrol kinerja pengurus dan efisiensi dalam penggunaan ATK (Esrtiawan \& Soebijono, 2018)

Menurut pengamat koperasi Joy Tulung (Tigauw, 2019), mengatakan masih ditemukan berbagai permasalahan yang sedang dialami koperasi yang ada di Indonesia, diantaranya citra kopersai, kemandirian koperasi serta kualitas SDM, manajemen, akses permodalan dan jaringan bisnis. Pentingnya memiliki SDM dalam kegiatan koperasi yang berkualitas diharapkan mampu bekerja secara maksimal dalam menghimpun serta menggerakan sumberdaya lain yang dibutuhkan untuk menangkap peluang usaha terutama dalam menghadapi masyarakat yang sudah go digital seperti saat sekarang ini (Tigauw, 2019).

Selain itu peran penting lainnya dalam mengembangkan koperasi adalah komitmen kerja para karyawan. Komitmen organisasi merupakan cerminan di mana karyawan mampu mengenali organisasi dan terikat kepada tujuan-tujuannya. Hal ini merupakan sikap kerja yang penting karena orang yang memiliki komitmen diharapkan dapat 
menunjukkan ketersediaannya untuk bekerja lebih keras demi mencapai tujuan organisasi dan memiliki kemauan yang lebih besar untuk tetap bekerja di suatu organisasi (Kreitner \& Kinicki, 2011). Komitmen kerja merupakan karakteristik personal yang dapat dihandalkan dan dipercaya (Byron, 2010). Melalui komitmen kerja karyawan yang tinggi akan menjaga dan meningkatkan komitmen organisasi, juga akan memudahkan mengkoordinasikan semua lini dari manager sampai pada karyawan.

Komitmen organisasi yang diterapkan dengan baik dapat menjaga koperasi untuk tetap pada jalurnya dalam mencapai tujuan organisasi. Komitmen organisasi yang kuat juga mencerminkan kondisi internal yang sehat. Hasil penelitian di perusahaan pembiayaan PT Tunas Mandiri Finance menunjukkan bahwa karyawan ringkat supervisor yang sudah mempunyai keterikatan kuat dengan organisasi tidak memiliki keinginan untuk pindah ke perusahaan lain. Tetapi karyawan tingkat staf yang belum mempunyai keterikatan kuat dengan organisasi masih mempunyai keinginan untuk pindah ke perusahaan lain (Prawitasari, 2016). Hal ini berarti jika komitmen organisasi semakin kuat akan semakin kecil pula tingkat turnover employees sehingga organisasi tidak akan dipusingkan oleh perekrutan karyawan karena tingginya tingkat turnover yang ada dalam organisasi. Untuk menekan tingkat turnover atau sering dikenal dengan tingkat keluar masuknya karyawan yang bekerja di organisasi, serta menjaga dan meningkatkan komitmen organisasi, harus ditunjang dengan pola pikir karyawan yang bertanggung jawab, loyal dan bisa diandalkan. Kriteria sumber daya manusia tersebut merupakan ciri dari karyawan yang bertanggung jawab terhadap pekerjaan yang telah dijalankan. Pekerja yang bertanggung jawab dalam menjalankan pekerjaanya akan dapat berjalan sesuai dengan tujuan organisasi.

Pekerja yang penuh dedikasi tinggi dan bertanggung jawab terhadap pekerjaanya atau mempunyai komitmen kerja, merupakan value asset bagi koperasi. Komitmen kerja yang tinggi menjadikan karyawan lebih mampu mengenali pekerjaannya sehingga dapat memberian dampak positif bagi organisasi tempat karyawan bekerja. Dengan kata lain karyawan yang memiliki komitmen kerja yang tinggi memiliki keterikatan yang kuat secara psikologis dan fisik dengan pekerjaannya. orang yang memiliki komitmen diharapkan dapat menunjukkan ketersediaannya untuk bekerja lebih keras demi 
mencapai tujuan organisasi dan memiliki kemauan yang lebih besar untuk tetap bekerja di suatu organisasi (Kreitner \& Kinicki, 2011). Pertumbuhan komitmen kerja yang cepat dapat membantu karyawan menyesuaikan diri terhadap pekerjaannya. Pertumbuhan komitmen kerja dapat tumbuh melalui kepemimpinanya, budaya organisasi yang dikelola dengan benar,serta reward yang diberikan pada karyawan.

Komitmen kerja karyawan pada KOPPAS 'Citra Kartini” Senggreng Sumberpucung Kabupaten Malang sangat beragam. Komitmen kerja karyawan pada KOPPAS 'Citra Kartini” jika dilihat secara keseluruhan masih ada masalah yaitu terdapat turnover karyawan. Turnover karyawan ini dipicu oleh perkembangan digitalisasi yang diterapkan pimpinan untuk kemajuan koperasi, sehingga turnover karyawan terjadi karena ada sebagian yang tidak bisa mengikuti program digitalisasi tersebut, ketidakmampuan karyawan menyesuaikan diri dengan kebijakan maka terjadi turnover. Hal ini merupakan salah satu yang menggambarkan masih kurangnya komitmen kerja karyawan di KOPPAS "Citra Kartini” untuk mau meningkatkan kompetensinya. Padahal bagi Koperasi "Citra Kartini” yang berdiri tahun 1992 sangat diperlukan dukungan karyawan yang mempunyai komitmen tinggi untuk bisa menjaga keberlanjutan koperasi yang sudah mempunyai banyak anggota sebanyak 1512 orang (per April 2019)

Dari fenomena yang mendasari dan teori-teori yang telah disampaikan diatas, maka penelitian ini dilakukan dengan tujuan untuk menganalisis pengaruhnya tanggapan karyawan tentang: gaya kepemimpinan, budaya organisasi dan reward terhadap komitmen kerja karyawan KOPPAS "Citra Kartini” Senggreng Sumberpucung Kabupaten Malang.

\section{TINJAUAN PUSTAKA}

\section{A. Gaya Kepemimpinan dan Pengaruhnya terhadap Komitmen Kerja}

Kepemimpinan adalah komponen dasar dari teori kepemimpinan itu sendiri. Gaya kepemimpinan yang efektif dapat digolongkan menjadi dua sudut pandang yaitu struktur kelembagaan dan konsiderasi. Struktur kelembagaan disusun untuk mendapatkan interaksi antara pemimpin dan kelompok serta melihat 
bagaimana cara pemimpin mengatur kegiatan-kegiatan kelompok dalam rangka mencapai tujuan organisasi. Kepemimpinan adalah proses mempengaruhi dalam penentuan organisasi, mendorong perilaku anggota organisasi untuk mencapai tujuan, mempengaruhi dalam upaya perbaikan kelompok dan budaya organisasi (Rivai \& Deddy, 2012).

Salah satu model gaya kepemimpinan adalah gaya kepemimpinan situasional Harsyer dan Blancard (Model of Situasional Leadership). Model kepemimpinan ini lebih menekankan pada keadaan yang sebenarnya atau lebih dikenal dengan kepemimpinan situasional adalah teori kepemimpinan yang lebih memperhatikan pada para karyawan. Teori Kepemimpinan Situasional Harsyer dan Blancard tersebut terbagi 4 perilaku kepemimpinan yang spesifik yaitu telling, sellling, participating dan delegating (Sedarmayanti, 2011).

Hasil penelitian Widianto yang dilakukan di RS Anak dan Bersalin dengan 120 responden karyawan menyatakan bahwa gaya kepemimpinan situasional mempunyai pengaruh positif dan signifikan terhadap komitmen kerja karyawan (Widianto, 2013). Penelitian lain yang sejalan dilakukan dengan 201 responden karyawan perbankan di DKI Jakarta menunjukkan bahwa gaya kepemimpinan memiliki pengaruh terhadap kepuasan kerja, kepercayaan dan komitmen organisasi (Zahra, 2015).

\section{B. Budaya Organisasi dan Pengaruhnya terhadap Komitmen Kerja}

Sutrisno (2010) menyatakan bahwa budaya organisasi adalah suatu perangkat yang berkaitan dengan sistem nilai, asumsi, atau norma yang telah berlaku dan keyakinan, yang telah disepakati dan diikuti oleh semua anggota organisasi, serta yang dipakai sebagai pedoman dalam menyelesaikan masalah dalam organisasi tersebut. Budaya organisasi merupakan kerangka yang menjadi pedoman karyawan untuk bekerja mencapai tujuan organisasi (Rivai \& Deddy, 2012). Penelitian lain yang dilakukan oleh Arifin (2010) menganalisis tentang pengaruh budaya organisasi terhadap komitmen kerja karyawan untuk meningkatkan kinerja karyawan yang dilakukan di koperasi BMT di Kecamatan 
Jepara. Hasil penelitiannya menyatakan bahwa budaya organisasi berpengaruh positif pada komitmen kerja karyawan (Arifin, 2010). Sama halnya dengan penelitiannya Hermayanti dan Rahmawati (2015) pada karyawan PT. Indofood Cbp Sukses Makmur, Tbk. Cabang Bandung. Penelitiannya juga menghasilkan bahwa budaya kerja secara utuh berpengaruh positif terhadap komitmen karyawan (Hermayanti \& Rahmawati, 2015). Menurut Sutrisno (2010), budaya organisasi yang kuat itu meletakkan kepercayaan, tingkah laku dan cara melaksanakan berbagai hal kegiatan itu tanpa perlu dipertanyakan lagi. Sebaliknya budaya organisasi itu dikatakan lemah jika tidak dapat memberikan penjelasan tentang gambaran dan batasan yang jelas tentang apa yang tidak boleh dilakukan dan boleh dilakukan. Pada kenyataannya studi-studi yang dilakukan pada budaya organisasi yang kuat menunjukkan tingkat keterlibatan karyawan yang begitu besar (Sutrisno, 2010).

\section{Reward dan Pengaruhnya terhadap Komitmen Kerja}

Menurut Suwarto (2010) reward atau imbalan dibagi dalam dua pengertian yaitu: intrinsic reward atau imbalan intrinsik dan ekstrinsik reward atau imbalan ekstrinsik. Imbalan yang sesuai dengan harapan karyawan akan menjadi motivasi meningkatnya komitmen kerja. Komitmen kerja yang tinggi akan menunjang loyalitas yang tinggi. Sebaliknya komitmen kerja yang rendah akan meningkatkan tingkat trun over karyawan (Suwarto, 2010).

Penelitian yang dilakukan oleh Yudhaningsih, Sintaasih, dan Riana (2016) pada Bank Perkreditan Rakyat di Kabupaten Gianyar menyatakan bahwa sistem reward dikatakan baik dan mampu menaikkan komitmen organisasi jika bisa meningkatkan kinerja kepala bagian sehingga hal tersebut dapat meningkatkan daya saing perusahaan (Yudhaningsih, Sintaasih, \& Riana, 2016). Penelitian lain yang dilakukan oleh Koencoro, Musadiq \& Susilo (2013), pada karyawan PT. INKA (persero) Madiun juga menunjukkan hasil adanya pengaruh simultan dan pengaruh yang signifikan tentang variabel reward karyawan dan punishment karyawan terhadap variabel kinerja karyawan (Koencoro, Musadieq, \& Susilo, 2013). Menurut Suwarto (2010) salah satu sasaran utama program imbalan ialah mempertahankan karyawan agar tetap bekerja keras. Dengan kata lain imbalan 
digunakan untuk mempertahankan komitmen kerja karyawan untuk tetap stabil dan meningkat. Penjelasan tersebut didukung dengan teori pertukaran sosial menurut pendapat Sutrisno (2010) setiap hubungan akan selalu mempertimbangkan untung dan rugi, sebagian besar hubungan termotivasi untuk memaksimalkan reward, sehingga partisipan dapat mereevaluasi hubungan untuk menjadi lebih berarti.

Dari uraian tersebut, dapat disimpulkan bahwa setiap hubungan memiliki timbalbalik yang sesuai. Dalam hal ini karyawan yang memberikan komitmennya kepada organisasi koperasi harus segera direspon oleh koperasi dengan memberikan reward yang sesuai dengan komitmen yang diberikan karyawan. Dalam studi yang dilakukan di beberapa organisasi koperasi yang menerapkan sistem reward yang baik yang sesuai antara pihak koperasi dan karyawan menghasilkan tingkat komitmen karyawan yang sangat tinggi, sehingga tingkat trun over karyawan pada suatu koperasi cenderung menurun dan jarang terjadi.

\section{Keterkaitan Antar Variabel dan Hipotesis}

Mengacu pada beberapa hasil penelitian diantaranya hasil penelitian Widianto (2013) dan (Zahra, 2015) menunjukkan bahwa gaya kepemimpinan memiliki pengaruh signifikan terhadap komitmen kerja karyawan sehingga dirumuskan hipotesis pertama sebagai berikut:

\section{H1 (hipotesis pertama) :}

Terdapat pengaruh signifikan gaya kepemimpinan terhadap komitmen kerja karyawan di KOPPAS “Citra Kartini” Senggreng Sumberpucung Kabupaten Malang.

Mengacu pada beberapa hasil penelitian diantaranya hasil penelitian Arifin (2010) dan Hermayanti dan Rahmawati (2015) menunjukkan bahwa budaya organisasi memeliki pengaruh signifikan terhadap komitmen kerja karyawan sehingga dirumuskan hipotesis pertama sebagai berikut:

\section{H2 (hipotesis kedua) :}

Terdapat pengaruh signifikan budaya organisasi terhadap komitmen kerja di KOPPAS “Citra Kartini” Senggreng Sumberpucung Kabupaten Malang. 
Mengacu pada beberapa hasil penelitian diantaranya hasil penelitian Yudhaningsih, Sintaasih, dan Riana (2016) serta Koencoro, Musadiq \& Susilo (2013) menunjukkan bahwa reward memiliki pengaruh signifikan terhadap komitmen kerja karyawan sehingga dirumuskan hipotesis pertama sebagai berikut:

\section{H3 (hipotesis ketiga) :}

Terdapat pengaruh signifikan reward terhadap komitmen kerja di KOPPAS “Citra Kartini” Senggreng Sumberpucung Kabupaten Malang.

\section{E. Kerangka Konseptual}

Berdasarkan hipotesis, maka kerangka konseptual pada penelitian ini dapat digambarkan dalam model seperti berikut:

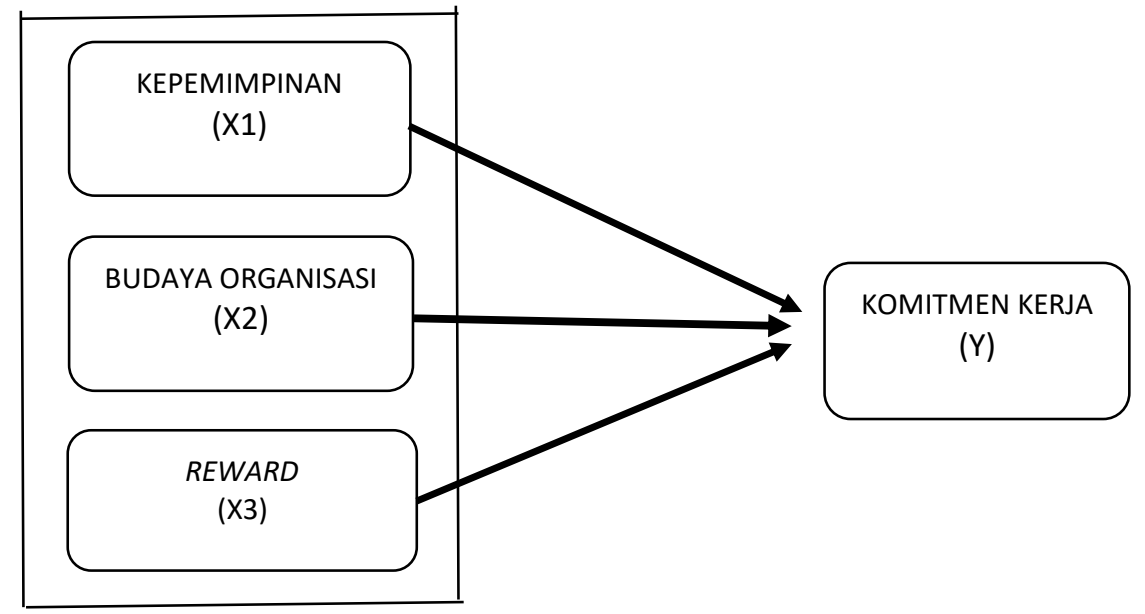

Gambar 1. Kerangka Konseptual

\section{METODE PENELITIAN}

Penelitian ini adalah penelitian deskriptif kuantitatif, dimana data yang digunakan dalam penelitian adalah data primer berupa pernyataan jawaban dari responden dari kuisioner yang diedarkan dan kemudian dengan menggunakan skala likert untuk dianalisis secara statistik. Dalam penelitian ini teknik analisis yang digunakan adalah regresi linier berganda. Penelitian ini dilakukan di Koperasi "Citra Kartini” Senggreng Sumberpucung Kabupaten Malang yang berdiri tahun 1992 dengan jumlah anggota sebanyak 1512 orang (per April 2019). 
Populasi dalam penelitian ini adalah seluruh karyawan di KOPPAS "Citra Kartini" Senggreng Sumberpucung Kabupaten Malang. Dan sampelnya menggunakan teknik sampel jenuh, karena jumlah populasi kurang dari seratus maka populasi tersebut juga sebagai sampel atau diambil semua, yaitu berjumlah 39 karyawan.

Adapun variabel dan indikator penelitian yang digunakan dalam penelitian ini seperti pada Tabel 1 berikut ini:

Tabel 1. Variabel dan Indikator Penelitian

\begin{tabular}{|c|c|c|c|}
\hline Variabel & Indikator & Item & Sumber \\
\hline $\begin{array}{l}\text { Variabel terikat } \\
\text { (Y) } \\
\text { Komitmen kerja }\end{array}$ & $\begin{array}{l}\text { Continuace } \\
\text { Commitment }\end{array}$ & $\begin{array}{l}\text { a.hubungan emosional } \\
\text { b.bagian dalam perusahaan } \\
\text { c.menjalankan pekerjaan } \\
\text { d.keputusan perusahaan } \\
\text { e.memegang teguh peraturan } \\
\text { a.kesadaran menjadi bagian } \\
\text { perusahaan } \\
\text { b.rugi tinggalkan perusahaan } \\
\text { c.membantu kesuksesan perusahaan } \\
\text { d.kebahagiaan hidup di perusahaan } \\
\text { e.loyalitas kepada perusahaan } \\
\text { a.keterkaitan dengan perusahaan } \\
\text { b.harus selalu berada di perusahaan } \\
\text { c.penghargaan terhadap perusahaan } \\
\text { d.bertanggung jawab dalam } \\
\text { perusahaan } \\
\text { e.kepedulian terhadap perusahaan }\end{array}$ & $\begin{array}{l}\text { Sutrisno } \\
\text { ( 2010) }\end{array}$ \\
\hline $\begin{array}{l}\text { Variabel Bebas } \\
\text { ( X1) } \\
\text { Gaya } \\
\text { Kepemimpinan } \\
\text { Situasional }\end{array}$ & $\begin{array}{l}\text { Directing } \\
\text { (Mengarahkan) } \\
\text { Coaching } \\
\text { ( melatih) } \\
\text { Supporting } \\
\text { ( mendukung) } \\
\text { Delegating } \\
\text { (Mendelegasikan) }\end{array}$ & $\begin{array}{l}\text { a.sifat struktural organisasi } \\
\text { b.iklim atau lingkungan } \\
\text { organisasi } \\
\text { karakteristik tugas atau peran } \\
\text { karakteristik bawahan } \\
\text { mendelegasikan tugas kepada } \\
\text { bawahan }\end{array}$ & $\begin{array}{l}\text { Sedarmayanti } \\
\text { (2011) }\end{array}$ \\
\hline $\begin{array}{l}\text { Variabel Bebas } \\
\text { (X2) Budaya } \\
\text { Organisasi }\end{array}$ & $\begin{array}{l}\text { Asas consensus } \\
\text { Asas tujuan }\end{array}$ & $\begin{array}{l}\text { a.menetapkan tujuan } \\
\text { b.fokus pada produk } \\
\text { c.fokus pada pelanggan } \\
\text { a.lebih baik } \\
\text { b.kreatif } \\
\text { c.lebih tegas } \\
\text { d.diikuti oleh tindakan }\end{array}$ & $\begin{array}{l}\text { Sutrisno } \\
(2010)\end{array}$ \\
\hline
\end{tabular}




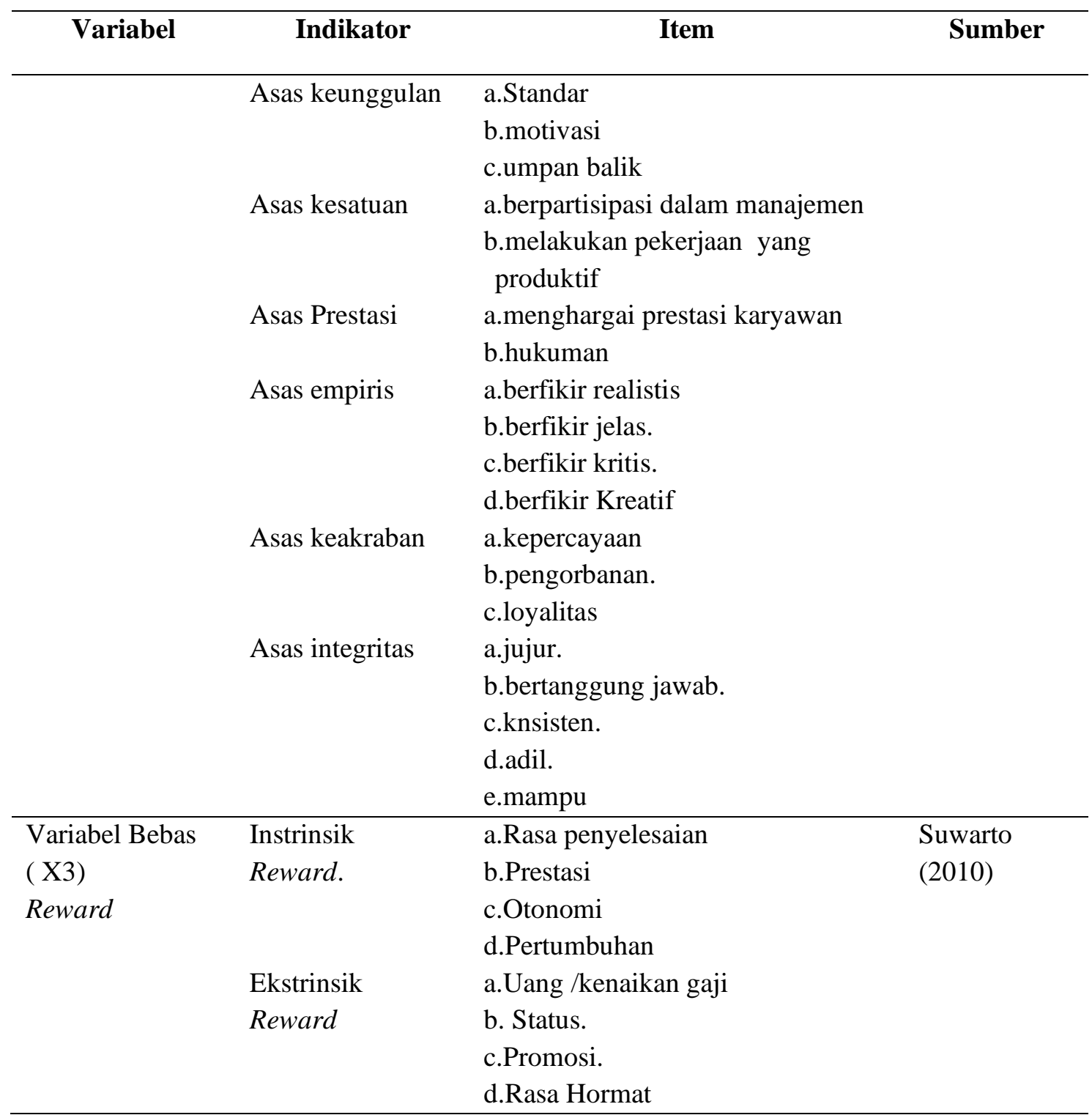

\section{HASIL DAN DISKUSI}

\section{A. Hasil Penelitian}

Hasil dari uji validitas dan realibilitas menunjukkan: 1) $\mathrm{R}$ hitung dari instrumen positif dan > (lebih besar) dari $\mathrm{R}$ tabel (0.374), maka butir-butir kuesioner atau instrumen dikatakan valid; 2) $\mathrm{R}$ hitung dari instrumen positif dan > (lebih besar) dari R tabel (0.374), maka butir-butir kuesioner atau instrumen dikatakan reliabel. Hasil dari uji asumsi klasik menunjukkan: 1) Koefisien korelasi antar variabel independen di bawah 0,5, berarti bebas dari multikolinieritas, 2) Penyebaran data pada histogram dan normal p-p plot of regression statistics terletak di sekitar garis diagonal dan mengikuti arah garis diagonal, berarti termasuk normal dan 
linier, 3) Penyebaran data pada Scatterplot tidak menunjukkan pola yang jelas, titik-titik menyebar di bawah dan di atas angka 0 pada sumbu Y, maka tidak terjadi heteroskedastisitas.

Hasil uji hipotesis dan analisa regresi berganda pada Tabel 2 menunjukkan hasil: 1) Koefisien gaya kepemimpinan $\left(X_{1)}\right.$ terhadap Komitmen $(Y)$ adalah 0,372, pada signifikansi 0,014, ini beararti ada pengaruh signifikan Gaya Kepemimpinan $\left(\mathrm{X}_{1}\right)$ terhadap Komitmen Kerja Karyawan, karena 0,014 lebih kecil (<) dari 0,05. Dengan demikian hipotesis 1 diterima; 2) Koefisien Budaya Organisasi $\left(\mathrm{X}_{2}\right)$ terhadap Komitmen (Y) sebesar 0,308 pada signifikansi 0,02, berarti ada pengaruh signifikan Budaya Organisasi $\left(\mathrm{X}_{2}\right)$ terhadap Komitmen Kerja Karyawan, ( 0.02 lebih kecil $(<)$ dari 0,05). Dengan demikian hipotesis 2 diterima; dan 3) Koefisien Reward $\left(\mathrm{X}_{3}\right.$ ) terhadap Komitmen (Y) sebesar 0,396 dengan pada signifikansi 0,011, ini berarti bahwa ada pengaruh yang signifikan Reward ( $\left.\mathrm{X}_{3}\right)$ terhadap Komitmen Kerja Karyawan, karena 0.011 lebih kecil $(<)$ dari 0,05. Ini berarti hipotesis 3 diterima. Dari hasil analisis dapat diketahui bahwa 4) Faktor yang berpengaruh dominan terhadap komitmen kerja karywan adalah reward yang ditunjukkan dengan koefisien regresi paling tinggi.

Tabel 2. Hasil Analisa Data

\begin{tabular}{lcc}
\hline \multicolumn{1}{c}{ Keterangan } & Koefisien Regresi (Beta) & Sig \\
\hline Konstanta & $-0,294$ & \\
Gaya Kepemimpinan (X1) & 0,372 & 0,014 \\
Budaya Organisasi (X2) & 0,308 & 0,020 \\
Reward (X3) & 0,396 & 0,011 \\
\hline Variabel Dependen (Y): Komitmen Kerja & \\
Sig F = 0,0000 & \\
R Square = 0,532 & \\
\hline
\end{tabular}

Sumber: diolah oleh peneliti, 2020

\section{B. Diskusi}

Dari penelitian ini didapatkan bahwa gaya kepemimpinan memiliki pengaruh signifikan terhadap komitmen kerja karyawan. Oleh karena itu variabel gaya kepemimpinan perlu diperhatikan, mengingat usia karyawan berbeda beda yakni remaja, senior dan cukup senior. Ada kecenderungan Gaya kepemimpinan masih perlu ditingkatkan artinya menekan emosional yang negatif misalnya daya emosi yang tinggi takterkendali, berangan-angan atau daya khayal yang tinggi tanpa 
dibarengi dengan kenyataan dalam bertindak, hal ini akan mempengaruhi dan menghambat dalam menjalankan pekerjaanya, yang pada akhirnya akan mempengaruhi komitmen kerja karyawan. Selain itu, yang perlu ditingkatkan adalah gaya kepemimpinan situasional yang positif yaitu melatih diri mengendalikan emosi yang berlebih dan berangan-angan yang dibarengi dengan kenyataan dalam bertindak, hal semacam ini akan mempunyai dampak positif dalam menjalankan pekerjaanya. Sebagaimana penelitian Widianto (2013), hasil penelitian ini menunjukkan gaya kepemimpinan situasional berpengaruh positif dan signifikan terhadap komitmen kerja karyawan. Penelitian Zahra (2015) menunjukkan bahwa gaya kepemimpinan berpengaruh terhadap kepuasan kerja, kepercayaan serta komitmen organisasi

Hasil penelitian ini menunjukkan bahwa budaya organisasi berpengaruh signifikan terhadap komitmen kerja karyawan. Hal ini sejalan dengan penelitian Arifin (2010). Selain itu hasil penelitian ini juga mendukung penelitian Hermayanti dan Rahmawati (2015)

Sedangkan untuk reward juga menunjukkan hasil yang sama yaitu selain mempunyai pengaruh signifikan terhadap komitmen kerja juga berpengaruh dominan. Hal ini berarti komitmen kerja karyawan dapat lebih optimal, jika diikuti pemberian reward yang sesuai dengan prestasi yang dicapai oleh karyawan. Hal ini mendukung penelitian Yudhaningsih, Sintaasih, dan Riana (2016) dimana pemberian reward yang baik dan mendukung komitmen organisasional akan berdampak pada peningkatan kinerja kepala bagian yang pada akhirnya akan meningkatkan daya saing perusahaan. Penelitian Koencoro, Musadiq, dan Susilo pada karyawan PT. INKA (persero) Madiun juga menunjukkan adanya pengaruh simultan dan signifikan variabel reward dan punishment karyawan pada kinerja karyawan.

Dari hasil analisis penelitian ini menunjukkan bahwa koefisien determinasi berganda ( $\mathrm{R}$ square) sebesar 0,532 ini berarti bahwa komitmen kerja karyawan, $53,2 \%$ dipengaruhi oleh gaya kepemimpinan, budaya organisasi dan reward, sedang sisanya sebesar $46,8 \%$ dipengaruhi oleh variabel lain yang tidak masuk dalam model penelitian ini (antara lain kemampuan pimpinan dalam mengelola 
organisasi, kemampuan karyawan dalam menjalankan tugasnya, kondisi keluarga, sikap pimpinan terhadap bawahan, sarana-prasarana yang ada dan sebagainya). Hal ini dapat dipahami karena komitmen kerja karyawan pada umumnya tidak hanya dipengaruhi oleh gaya kepemimpinan, budaya organisasi dan pemberian reward saja. Berdasarkan uraian di atas perlu adanya pemikiran dan upaya secara maksimal untuk meningkatkan kinerja karyawan, misal, pemberian reward bagi karyawan berprestasi dan pemberian punishment bagi mereka yang bekerja kurang baik.

Oleh karena itu, KOPPAS : “Citra Kartini” Sumber Pucung Kabupaten Malang disarankan untuk memperhatikan beberapa hal yakni masalah reward, gaya kepemimpinan dan kualitas SDM. Masalah reward karyawan perlu mendapat perhatian karena karyawan pasti akan sangat menyambut adanya kebijakan pimpinan untuk memberikan reward atau hadiah yang diberikan kepada mereka. Pemberian reward ini diharapkan dapat memberikan alternatif solusi cerdas tentang permasalahan yang terjadi dalam organisasi yaitu mengurangi angka turnover bagi karyawan. Pemberian reward kepada karyawan diharapkan dapat mengurangi atau bahkan tidak ada turnover karyawan karena baik gaji dan reward yang diterima sudah sesuai dengan pekerjaan yang dilakukan, yang pada akhirnya akan berpengaruh signifikan terhadap komitmen kerja karyawan KOPPAS : "Citra Kartini” Sumber Pucung Kabupaten Malang.

Selain pemberian reward, diharapkan pimpinan menerapkan gaya kepemimpinan situasional. Hal ini karena gaya situasional merupakan gaya atau model kepemimpinan yang sangat diharapkan oleh karyawan yaitu saat-saat tertentu menggunakan model yang serius, dan saat-saat tertentu pula menggunakan model atau gaya kekeluargaan tapi tetap menggunakan koridor kepemimpinan yang baik. Selain hal tersebut diatas pimpinan KOPPAS Citra Kartini, hendaknya berupaya meningkatkan kualitas SDM dengan beberapa cara antara lain: karyawan perlu ditingkatkan pendidikannya, diikutsertakan kursus untuk memperdalam tentang IT, diikutsetakan seminar, diikutsertakan workshop dan diajak studi banding ke koperasi lain agar karyawan lebih meningkat wawasannya sehingga bisa meningkatkan kinerjanya. 


\section{KESIMPULAN DAN SARAN}

Hasil analisis data dalam penelitian ini dapat disimpulkan: 1) gaya kepemimpinan berpengaruh positif signifikan terhadap komitmen kerja karyawan, 2) budaya organisasi berpengaruh positif signifikan terhadap komitmen kerja karyawan, 3) reward berpengaruh positif signifikan terhadap komitmen kerja karyawan, dan 4) reward merupakan variabel yang berpengaruh dominan terhadap komitmen kerja karyawan

Berdasarkan kesimpulan tersebut, disarankan KOPPAS: "Citra Kartini” Sumber Pucung Kabupaten Malang disarankan untuk memperhatikan beberapa hal yaitu : 1) masalah reward karyawan. Pemberian reward kepada karyawan diharapkan dapat mengurangi atau bahkan tidak ada turnover karena gaji dan reward yang diterima dianggap sudah memadai dibanding dengan pekerjaan yang dilakukan; 2) diharapkan pimpinan menerapkan gaya kepemimpinan situasional, hal ini karena gaya situasional merupakan gaya atau model kepemimpinan yang sangat diharapkan oleh karyawan, dimana pada saat-saat tertentu menggunakan model yang serius, dan saat-saat tertentu pula menggunakan model atau gaya kekeluargaan tapi tetap menggunakan koridor kepemimpinan yang baik; dan 3) meningkatkan kualitas SDM antara lain dengan cara meningkatkan pendidikan karyawan, diikutsertakan kursus untuk memperdalam IT, diikutsertakan dalam seminar, workshop dan studi banding ke koperasi lain, dengan tujuan untuk meningkatkan wawasannya yang berdampak pada peningkatan kinerja mereka.

\section{DAFTAR PUSTAKA}

Arifin, N. (2010). Analisis Budaya Organisasi Terhadap Komitmen Kerja Karyawan dalam Peningkatan Kinerja Organisasional Karyawan Pada Koperasi BMT Di Kecamatan Jepara . Jurnal Ekonomi \& Pendidikan, 8 (2): 173-192.

Byron, W. (2010). The Power Priciples. Yogyakarta: Kanisius.

Esrtiawan, M. S., \& Soebijono, T. (2018). Analisis Good Corporate Governance (Pendekatan Sistem Informasi Studi Kasus Pada Koperasi Seta Bhakti Wanita di Surabaya). Develop, 2(1).

Hermayanti, A., \& Rahmawati, S. (2015). Pengaruh Budaya Kerja Terhadap Komitmen Kerja Kryawan PT Indofood CBP Sukses Makmur Tbk Cabang Bandung Divisi Noodle. Jurnal Manajemen dan Organisasi, 6 (2): 150-160. 
Koencoro, G. D., Musadieq, M. A., \& Susilo, H. (2013). Pengaruh Reward dan Punishment terhadap Kinerja. Jurnal Administrasi dan Bisnis, 5 (2), 1-8.

Kreitner, R., \& Kinicki. (2011). Organizational Behavior. Jakarta: Salemba Empat.

Prawitasari, A. (2016). Faktor-faktor yang Mempengaruhi Turnover Intention Karyawan PT Mandiri Tunas Finance Bengkulu. Ekombis Review, 4(2), 177186.

Rivai, V., \& Deddy, M. (2012). Kepimpinan dan Perilaku Organisasi. Jakarta: PT Raja Grafindo Persada.

Sedarmayanti. (2011). Membangun dan Mengembangkan Kepemimpinan serta Meningkatkan Kinerja untuk Meraih Keberhasilan. Bandung: PT Reflika Aditama.

Sutrisno, E. (2010). Budaya Organisasi. Jakarta: Kencana Prenada Media Grup.

Suwarto, F. (2010). Perilaku Keorganisasian. Yogyakarta: Universitas Atmajaya.

Tigauw, N. L. (2019). antaranews.com. Retrieved from https://www.antaranews.com/berita/957621/mengubah-citra-koperasi-yangketinggalan-zaman

Widianto, A. B. (2013). Pengaruh Gaya Kepemimpinan Situasional dan Motivasi terhadap Komitmen dan Prestasi Kerja Karyawan Rumah Sakit Anak dan Bersalin Muhammadiyah Tuban. Jurnal Ekonomi dan Manajemen, 9(2), 154183.

Yudhaningsih, N. M., Sintaasih, D. K., \& Riana, I. G. (2016). Hubungan Sistem Reward Dengan Komitmen Organisasional Dan Pengaruhnya Terhadap Kinerja ( Studi Pada Bank Perkreditan Rakyat di Kabupaten Gianyar ). E-Jurnal Ekonomi dan Bisnis Universitas Udayana, 5 (7): 2261-2296.

Zahra, N. (2015). Pengaruh Gaya kepemimpinan Terhadap Komitmen Organisasi Melalui Aspek Kepuasan Kerja Karyawan dan Kepercayaan Pada Sektor Perbankan. Jurnal Manajemen dan Pemasaran Jasa, 8 (1), 145-162. 